\title{
Orthopteran fauna of the Hel Peninsula in Poland
}

\author{
Kateřina KuŘAvovÁ \\ Department of Biology and Ecology, University of Ostrava, Chittusiho 10, CZ-710 00 Ostrava, Czech Republic \\ email: Kuravova.katerina@seznam.cz
}

\begin{abstract}
Grasshoppers and katydids (Orthoptera) were studied on sand dunes of the Hel Peninsula in northern Poland in 2013. Altogether, 11 species of grasshoppers and katydids were identified, three of them can be regarded as elements of the fauna characteristic for sand dunes. Species diversity and population density was higher in the seaside with sparse vegetation than in the neighboring pine forest. The reported low species richness is comparable to other peninsula covered by sand. Myrmeleotettix maculates was most abundant, particularly by the seaside with low shrubs and Tetrix bipuncata occurred frequently in each habitat, but especially on the forest gaps.
\end{abstract}

Key words: grasshopper, katydids, locusts, xerothermic species, sandbanks, dune habitats

\section{INTRODUCTION}

The fauna of Orthoptera in coastal dunes have been investigated rather extensively (Decleer \& Devriese 1992, Malkus et al. 1993, Folger \& Handelmann 1999, Spungis 2007). Coastal dune grasslands have been dramatically reduced in the area of most European countries, mainly due to building activities for tourism (De Ruyck et al. 2001). In Latvia, dunes are reported as a characteristic habitat for several endangered species (i.e. Oedipoda coerulescens (Linnaeus, 1758), Sphingonotus caerulans Linnaeus, 1767) (Spuris 1998).

In Poland, 82 species of the orthopterans are reported (Bazyluk \& Liana 2000). The Hel Peninsula separates Puck Bay (the southwestern part of Gdańsk Basin) from the open Baltic Sea. The Hel Peninsula has evolved during the Holocene. Its coast is basically of recent alluvial and littoral zone Holocene sediments (Furmańczyk 2004). From the Hel Peninsula only three species of orthopteran insects are reported: Platycleis albopunctata (Goeze, 1778), Tetrix bipunctata (Linnaeus, 1758) and Sphingonotus caerulans (Brischke 1888, La Baume 1911, 1920, Sokolowski 1928, Bazyluk 1954). On the coast near the Gulf of Gdańsk were reported 13 orthopteran species The Orthoptera fauna of the coast of the Gulf of Gdańsk (near the Hel Peninsula) consists 13 species. (Zacher 1917, La Baume 1920, Bazyluk \& Liana 2000).

The aim of the study is to know what Orthoptera species occur in the various habitats of the Hel Peninsula.

\section{STUDY AREA, MATERIAL AND METHOD}

The Hel Peninsula is a long and narrow mass of land, extending $36 \mathrm{~km}$ east of Wladyslawowo (near the Tricity - Gdańsk, Gdynia and Sopot) out into the Baltic Sea, with a width varying between $100 \mathrm{~m}$ and $3 \mathrm{~km}$. The average annual precipitation and the average precipitation in the vegetation period (May-July) are $528 \mathrm{~mm}$ and $156 \mathrm{~mm}$, respectively. July is the warmest month, with a daily average temperature ranging from 16.6 to $17.7^{\circ} \mathrm{C}$. The average number of frost days is 89.4 (Wojterski \& Bednorz 1982). The vegetation consists of 204 plant species with 155 genera and 50 families. The most numerously represented families 
are Compositae, Gramineae, Rosaceae, and Leguminosae (Blaszkowski 1994). The dominant tree species is pine (Pinaceae).

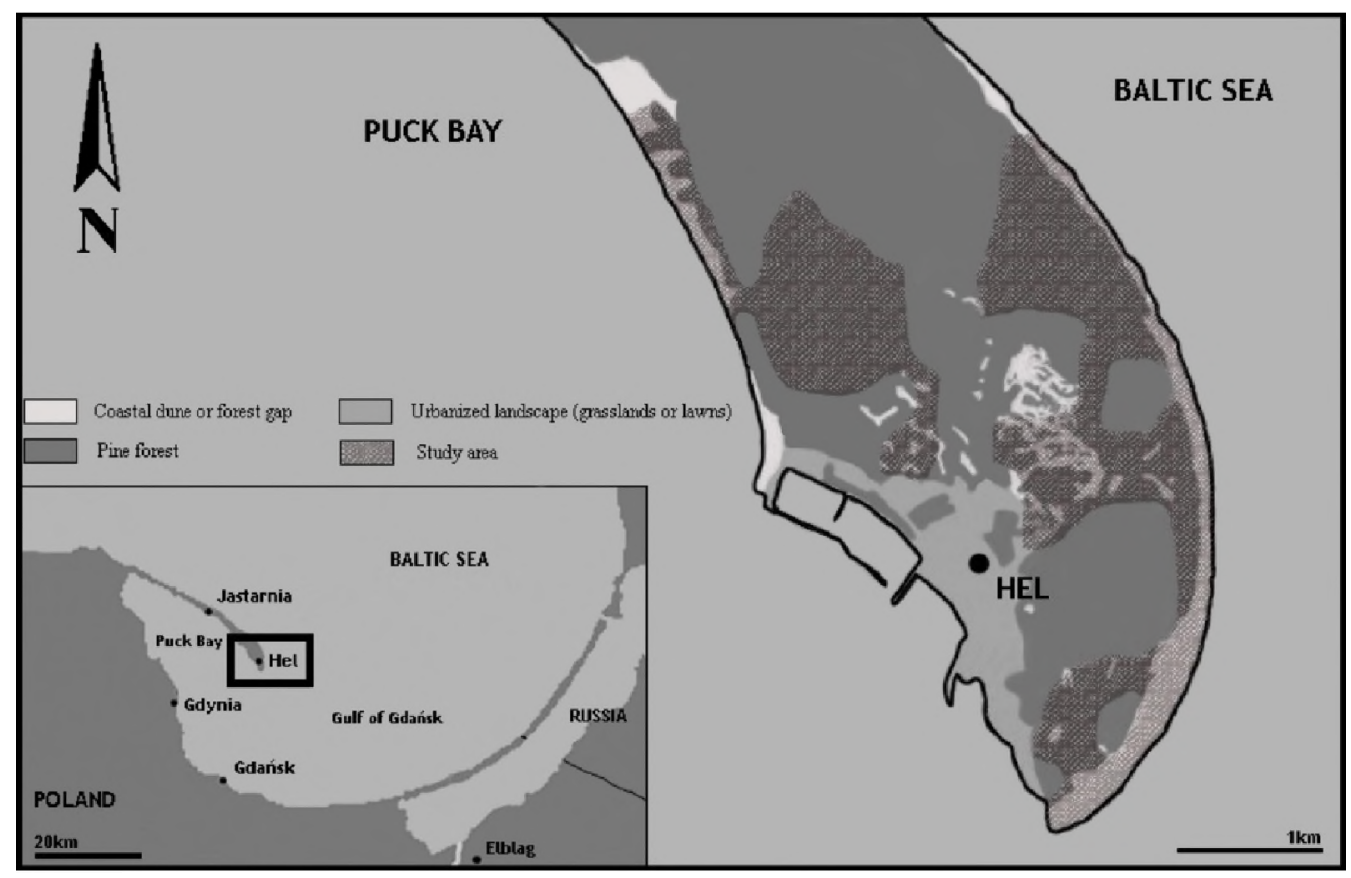

Figure 1. Map of Hel Peninsula and habitat sampled for Orthoptera.

The various study sites were selected to contain the widest spectrum of habitats of the Hel Peninsula. The orthopterans were collected from four habitats of the Hel Peninsula near the town Hel in various habitats (Fig. 1):

1. Pine forest $(\mathrm{F})$ : Dry pine forests (Pinaceae) are dominant vegetation on the Hel Peninsula. The characteristic pines are Pinus nigra Arn., P. sylvestris L. and P. mugo Turra. The shrub layer is rather poor. There are local depressions in the forest. The areas with sparse wood as peat-bogs or wet sites are overgrown by Empetrum nigrum L. or Ledum palustre $\mathrm{L}$. The important group consists of mosses (Dicranum sp., Sphagnum sp., Leucobryum sp.) and lichens (Cladonia sp., Cetraria sp.).

2. Coastal dune $(C)$ : The dunes covers a narrow strip, from $30 \mathrm{~m}$ up to $50 \mathrm{~m}$ wide, around the peninsula. The dunes consists of two parts: the white narrow and low, gradually transforming into the grey dune. The width of a typical grey dune is about $20 \mathrm{~m}$. The inland grey dunes are bordered by the dry pine forest or grasslands. The flower vegetation cover and the number of plant species increase with distance from the sea - from white dune to grey dune. The present herb layer contains species which belong to the families Asteraceae, Brassicaceae, Caryophyllaceae, Cyperaceae, Fabaceae, Lamiaceae, Poaceae (e.g. Acinos arvensis (Lam.) Dandy, Arenaria serpyllifolia L., Artemisia campestris L., Berteroa incana (L.) DC. Carex arenaria L., Corynephorus canescens (L.) P. Beauv., Lathyrus maritimus L., Trifolium arvense $\mathrm{L}$.

3. Grassland (G): Dry meadow with an area of 300 square meters in the middle of the pine forest. The vegetation is dominated by the grasses from the Poaceae and Cyperaceae families and contains the herbs from the families Boraginaceae, Brassicaceae, Crassulaceae, 
Solanaceae, Urticaceae (e.g. Corynephorus canescens; Berteroa incana, Echium vulgare L., Hyoscyamus niger L., Sedum acre L., Urtica dioica L.).

4. Lawn (L): The urban area includes ruderal herbaceous vegetation between the buildings, with dominant grasses of Cyperaceae and Poaceae.

The material was gathered every day from 15 th June to 28th June 2013. Orthopterans were primarily collected from herbal and partially shrub vegetation by sweeping (min. 50 sweeps with standard sweep net of $38 \mathrm{~cm}$ diameter). Daily time of collection was three hours at each plot. Sample size was dependent on habitat and was 3 individuals on average in 10 sweeps.

The orthopterans (adults) were identified directly in the field, but nymphs were fixed using $70 \%$ ethanol and determined in the laboratory using identification keys (Bazyluk 1956, Kočárek et al. 2013). The nomenclature of Orthopera insects is used according to Kočárek et al. (2005), and of plants according to Kubát et al. (2002).

\section{RESULTS AND DISCUSSION}

In total 126 adults and 42 nymphs of Orthoptera were collected. Eleven species of katydids, grasshoppers and groundhoppers were recorded in the Hel Peninsula (Table 1). This is less than $10 \%$ of the species known in Poland. Similar habitats in the coastal dunes (in Belgium, Denmark, Latvia) had 10-23 species (Decleer \& Devriese 1992, Folger \& Handelmann 1999, Spungis 2007). Range of the most of the recorded species is limited to the Eurosiberian or European region and corresponds to dry grasslands or sandbanks. The species richness differs between the study habitats. The highest number of species was found on the coastal dunes (Table 1). Tetrix bipunctata, Myrmeleotettix maculatus and Chorthippus brunneus were the species with the biggest number of individuals cought. In dry habitats Myrmeleotettix maculatus and Chorthippus brunneus are frequently found (Holst 1986). The groundhopper Tetrix bipunctata is the specific xerothermic species and it was found in all sites of the Hel Peninsula. T. bipunctata inhabits dry short grasslands with partly open soil (Baur et al. 2006). In addition, it can also be present on relatively dry, nutrient-poor forest clearings with sunny, open and mossy areas. This species has a specific life cycle - the individuals hibernate as adults and can be found all the year round. It is observed to be most common in autumn and spring (Baur et al. 2006, Kočárek et al. 2013). Usually, in the early summer, more nymphs than adults are observed but we recorded only adult individuals.

The thermo- and xerophilic species Myrmeleotettix maculatus is one of the smallest European Acrididae. It especially colonizes sand grasslands, dry moorland with open peat spots or stony pastures in the mountains (Detzel 1998). In dry sandy habitats it can reach high densities (Ingrisch \& Köhler 1998) and can be a dominant Orthoptera species (Schirmel et al. 2010). Adults are present from early May and can still be observed in early October (Kočárek et al. 2013).

Chorthippus brunneus is a widespread species, but prefers somewhat drier habitats. The habitats with high abundance of the species are often dry and sunny, often woodland clearings or edges and sometimes rocky areas. Furthemore, Ch. brunneus is observed also in nutrient-poor grasslands, on dry agricultural meadows, on embankments and roadsides, in ruderal localities and in gardens but it often occurs only in low density (Ingrisch \& Köhler 1998, Bazyluk \& Liana 2000, Kočárek et al. 2013). In Poland it is widespread (Bazyluk \& Liana 2000).

The pine forest is dominating in the Hel Peninsula and the typical Orthoptera species for such habitat Chorthippus vagans (Eversmann, 1848) was also found there. This grasshopper species inhabits xerothermous areas as sandy pine forests, rocky slopes, dry grasslands and similar areas, usually close to forest habitats (Kočárek et al. 2013). In Poland it is present in 14 
regions from the Baltic Coast to the Pieniny Mts. (Bazyluk \& Liana 2000). The pine forest is sparse in place sand and allows the xerothermic species to survive (Holuša 2000).

Table 1. Orthoptera recorded from the Hel Peninsula, Poland; $\mathrm{F}$ - pine forest, $\mathrm{C}$ - coastal dune, $\mathrm{G}$ - grassland, $\mathrm{L}$ lawn. Abundance category: (1) - very rare, less than 3 individuals cought during the study, (2) - rare, 3-10 ind., (3) abundant, more than 10 individuals. Observations from the Hel Peninsula or the Polish Baltic Coast according to Bazyluk \& Liana (2000), BC - the Baltic Coast of Poland or HEL - the Hel Peninsula.

\begin{tabular}{|r|l|c|c|c|c|c|}
\hline No & \multicolumn{1}{|c|}{ Species /Habitats } & $\mathrm{F}$ & $\mathrm{C}$ & $\mathrm{G}$ & $\mathrm{L}$ & Observation \\
\hline & Ensifera & & & & & \\
1 & Pholidoptera griseoaptera (De Geer, 1773) & & & 3 & & BC \\
2 & Platycleis albovittata (Goeze, 1778) & & 1 & 3 & & HEL \\
3 & Tettigonia viridissima Linnaeus, 1758 & & 3 & 3 & & BC \\
& Caelifera & 3 & 3 & 2 & 2 & BC, HEL \\
4 & Tetrix bipunctata (Linnaeus, 1758) & & 3 & & 2 & BC \\
5 & Oedipoda caerulescens (Linnaeus, 1758) & & 3 & & & HEL \\
6 & Sphingonotus coearulans Linnaeus, 1767 & & & 2 & 3 & BC \\
7 & Chorthippus apricarius (Linnaeus, 1758) & & 3 & 3 & 3 & BC \\
8 & Chorthippus brunneus (Thunberg, 1815) & & 1 & & 3 & BC \\
9 & Chorthippus mollis (Charpentier, 1825) & 3 & & & & BC \\
10 & Chorthippus vagans (Eversmann, 1848) & 2 & 3 & & 2 & BC \\
\hline
\end{tabular}

The most diverse habitat was the seaside with the various sites, from the bare soil to shrub vegetation (as Rosaceae). It corresponds to several Orthoptera species. Tettigonia viridissima Linnaeus, 1758 inhabits open areas of all types (fields, grasslands) as well as hedgerows, clear cuttings, parks or woodland edges. It prefers warm and rather dry lowland habitats. The distribution extends across most of Europe and temperate Asia (Holst 1986) and is not characteristic for dunes. The katydid Platycleis albopunctata has been recorded from the Hel Peninsula by previous authors (Brischke 1888, La Baume 1920, Bazyluk 1954). It is a subatlantic species, it occurs in all regions of Poland with exception of the Carpathian Mountains (Bazyluk \& Liana 2000). This species colonizes rich grasslands or sandy areas and bare slopes.

Pholidoptera griseoaptera occurred in the Hel Peninsula only on edges of grasslands near the pine forest. The individuals moved to the taller vegetation, such as shrubs or herbs (frequently on the Urticaceae). It is one of the most widespread and common bush cricket particularly in forest area and it occurs throughout much of Europe (Maas et al. 2002). Other vegetation types such as meso- and xerothermic grasslands and reed beds (Samietz 1995) may serve as additional feeding habitats. It is abundant in Poland (Bazyluk \& Liana 2000).

The blue-winged grasshopper Oedipoda caerulescens is a Palearctic species and inhabits sandy grasslands, rocky slopes or fine-earth rich steppe-like heathland (Appelt \& Poethke 1997) or it lives on railway corridors and sand pits. The individuals occurred often in the coastal dune and seldom in the lawn in the Hel Peninsula. The same pattern as Oedipoda caerulescens showed the grasshopper Sphingonotus caerulans. It is known as inhabitant of sandy grasslands or inland dunes (...).

In the extensive lawn of the Hel Peninsula occurred also Chorthippus apricarius and $C h$. mollis. Ch. apricarius requires grasslands and at least small gappy areas with open soil. Ch. mollis inhabits warm and dry, nutrient-poor grasslands and sandy grasslands. This species is endangered by the quantitative and qualitative decline of suitable grasslands due to the well- 
known factors eutrophication, agricultural intensification and overbuilding (Kuijken et al. 2003).

The sandy Hel Peninsula is inhabited by species of Orthoptera which tolerate the specific conditions. These are mainly psammophilic, xerophilous or pioneer organisms.

\section{ACKNOWLEDGEMENTS}

This research was supported by an Institutional Research Support grant from the University of Ostrava (reg. no. SGS21/PřF/2013, SGS24/PřF/2014).

The author is grateful to Dr. Petr Kočárek (CZE) for help in the identification of nymphs (Orthoptera).

\section{REFERENCES}

APPELT M. \& POETTHKE H. J. 1997. Metapopulation dynamics in a regional population of the blue-winged grasshopper (Oedipoda caerulescens; Linnaeus, 1758). Journal of Insect Conservation 1: 205-214.

Baur B., Baur H., Roesti C. \& Roesti D. 2006. Die Heuschrecken der Schweiz. Bern, Stuttgart, Wien, Haupt Verlag, $352 \mathrm{pp}$.

BAZYLUK W. 1954. Badania nad prostokrzydlymi (Orthoptera), karaczanami (Blattodea) i skorkami (Dermaptera) pólnocno-zachodniej Polski. Prace Komisji Biologicznej Wydziału Matematyczno-Przyrodniczego, Poznań, 15: $131-147$.

BAZYLUK W. 1956. Prostoskrzydłe - Orthoptera (Saltatoria). Klucze do oznaczania owadów Polski. PTE, Warszawa, $\mathrm{XI}, 166 \mathrm{pp}$.

BAZYLUK W. \& LIANA A. 2000. Prostoskrzydle Orthoptera. Katalog fauny Polski. MilZ PAN, Warszawa, XVII, 3, 156 pp.

BEASZKOWSKI J. 1994. Arbuscular fungi and mycorrhizae (Glomales) of the Hel Peninsula, Poland. Mycorrhiza 5: 71-88.

BRISCHKE C. G. A. 1888. Bericht über eine Excursion nach Hela während des Juli 1887. Naturforschende Gesselschaft in Danzig, Danzig, N. F., vol. 7: 42-64.

DE RUYCK A. M. C., AMPE C. \& LANGOHR R. 2001. Management of the Belgian coast: opinions and solutions. Journal of Coastal Conservation 7: 129-144.

DECLEER K. \& DEVRIESE H. 1992. Faunistics and ecology of the grasshoppers and crickets (Saltatoria) of the dunes along the Belgian coast. In: VAN GOETHEM J. L. \& GROOTAERT P. (eds), Faunal inventories of sites for cartography and nature conservation. Proceedings of the 8th international colloquium of the European Invertebrate Survey, Brussels, 9-10 September 1991. Institut Royal des Sciences Naturelles de Belgique, Brussels: 177-187.

DETZEL P. 1998. Die Heuschrecken Baden-Württembergs. Eugen Ulmer, Stuttgart, 580 pp.

FOLGER M. \& HANDELMANN D. 1999. Heuschrecken (Orthoptera: Saltatoria) in den Küstendunen von Houstrup Strand (West-Jutland). Faunistisch-Oekologische-Mitteilungen, 26, Suppl.: 95-104.

FuRMAŃtZYK K. 2004. Hel Peninsula (Poland). Eurosion Case Study, 28 pp. Available from: http:/copranet.projects.eucc-d.de/files/000143_EUROSION_Hel_peninsula.pdf 30 (Sep 2014)

HoLUŠA J. 2000. K poznání sarančí (Caelifera) a kobylek (Ensifera) Moravskoslezských Beskyd. - Klapalekiana 36 41-70.

HOLST K. Th. 1986. The Saltatoria (Bush-crickets, crickets and grasshoppers) of Northern Europe. Fauna Entomologica Scandinavica 16:1-127.

INGRISCH S. \& KöHLER G. 1998. Die Heuschrecken Mitteleuropas, Die Neue Brehm-Bücherei Bd. 629. Westarp Wissenschaften, Magdeburg, 1-450.

KOČÁREK P., HOLUŠA J. \& VIDLIČKA L. 2005. Blattaria. Mantodea. Orthoptera \& Dermaptera of the Czech and Slovak Republics. Kabourek, Zlín, 349 pp.

KOČÁREK P., HOLUŠA J., VLK R. \& MARHOUL P. 2013. Rovnokř́dlí České republiky (Insecta: Orthoptera). Academia, $283 \mathrm{pp}$.

KubÁt K., Hrotda L., ChrTeK J. JUN., KAPLAN Z., KIRSCHNER J. \& ŠTĚPÁNEK J.(eds) 2002. Klíč ke květeně České republiky. Academia, Praha, 928pp.

KUIJKEN E., TACK J. \& BRUYN L. D. 2003. State of Nature in Flanders. Chapter 6: Biodiversity in the Regions and the North Sea. Biodiversity of Belgium, a country study, $416 \mathrm{pp}$.

LA BAUME W. 1911. Orthopterologisches aus Westpreussen. Entomologische Rundschau, Stuttgart, 28: 158-159.

LA BAUME W. 1920. Die Geradflüglerfauna Westpreussens. Dritter Beitrag zur Kenntnis der westpreussischen Ohrwürmer und Heuschrecken (Dermaptera und Orthoptera). Naturforschende Gesselschaft in Danzig, Danzig, 15: $144-185$.

MAAS S., DETZEL P. \& STAUDT A. 2002. Gefährdungsanalyse der Heuschrecken Deutschlands. Bundesamt für Naturschutz, Bonn-Bad Godesberg, 401 pp. 
MALKUS J., RÜHLE W., PURPS J. 1993. Zur Kenntnis der Heuschreckenfauna unterschiedlich stark genutzter Dünenbereiche auf dem Daß im Nationalpark Vorpommersche Boddenlandschaft. Natur und Naturschutz in Mecklenburg-Vorpommern 30: 6466.

SAMIETZ J. 1995. Die heuschreckenfauna (Orthopteroidea: Ensifera, Caelifera) des truppenübungsplatzes Ohrdruf (Thüringen). Thüringen Fauna Abhandlung 2: 73-84.

SCHIRMEL J., BUCHHOLZ S. \& FARTMANN T. 2010. Is pitfall trapping a valuable sampling method for grassland Orthoptera? Journal of Insect Conservation 14: 289-296.

SOKOEOWSKI J. 1928. Fauna owadów prostoskrzydlych (Orthoptera) województwa poznańskiego. Prace Komisji Matematyczno-Przyrodniczej Poznańskiego Towarzystwa Przyjaciół Nauk, Poznań, 4: 97-168.

SPUNGIS V. 2007. Fauna and Ecology of Grasshoppers (Orthoptera) in the Coastal Dune habitats in Ziemupe Nature Reserve, Latvia. Latvijas entomologs 44: $58-68$.

SPURIS Z. 1998. Red Data Book of Latvia. Rare and threatened species of plants and animals. Invertebrates. 4. Riga, Institute of Biology, $388 \mathrm{pp}$.

WOJTERSKI T. \& BEDNORZ J. 1982. Pobrzeże Słowinskie i Kaszubskie Przyroda polska. Wiedza Powszechna, 223 pp.

ZACHNER F. 1917. Die Geradflügler Deutschands und ihre Verbreitung. Systematisches und synonimisches

Verzeichniss der im Gebiete des Deutschen Reiches bisher aufgefundenen Orthopteren-Arten (Dermaptera, Oothecaria, Saltatoria). Jena, 8: $287 \mathrm{pp}$

\section{STRESZCZENIE}

\section{[Fauna Orthoptera na Pólwyspie Helskim]}

W pracy przedstawiono wyniki badań prostoskrzydłych znalezionych na piasku Półwyspu Helskiego. Stwierdzono występowanie 11 gatunków, w tym trzy uznane za charakterystyczne dla wydm. Liczba gatunków i zagęszczenie populacji bylo wyższe nad brzegiem morza z rzadką roślinnością niż w przyleglym lesie sosnowym. Niższe bogactwo gatunkowe związane jest z suchym klimatem i niską różnorodnością siedliska i jest porównywalne do innych piaszczystych półwyspów. 